\title{
Facial Profile Analysis by Photometry on W. R. Supratman $1 \& 2$ Chinese High School Students in Medan
}

\author{
Wilson Hartanto ${ }^{1 *}$, Hilda Fitria Lubis ${ }^{2}$ \\ ${ }^{1}$ Faculty of Dentistry, University of North Sumatra, Medan 20155, Indonesia \\ ${ }^{2}$ Department of Orthodontics, Faculty of Dentistry, University of North Sumatra, Medan 20155, \\ Indonesia \\ *Email: wilhartanto94@gmail.com
}

\begin{abstract}
Analysis of the facial profile is required for diagnosis and treatment planning in orthodontics. The Mongoloid Chinese race tends to have a flat facial profile and a more prominent zygomatic arch. The aim of this study was to identify the facial profile of Chinese high school students at W.R. Supratman 1 and 2 in Medan by photometry. An analytical descriptive study with a cross-sectional design was applied. The sample was compromised of 100 high school students (50 males and 50 females). The results showed no differences in facial profile between males and females using the Graber method. The straight profile comprised the highest percentage of participants, which was $62 \%$ of males and $68 \%$ of females, and the convex profile was $20 \%$ of males and $16 \%$ of females. The concave profile comprised the lowest percentage, which was $18 \%$ of males and $16 \%$ of females $(p=0.811)$. The results of the Singh method showed that the straight profile comprised the highest percentage at $70 \%$ of males and $62 \%$ of females, whereas the convex profile comprised $14 \%$ of males and $16 \%$ of females. The concave profile had the lowest percentage, which was $14 \%$ of males and $16 \%$ of females $(p=0.676)$. We conclude that gender had no significant effect on facial profile in a group of Chinese high school students.
\end{abstract}

Keywords: facial profile, photometry, Graber method, Singh method

\section{Introduction}

Symmetrical facial esthetics and functional occlusion is an orthodontic treatment goal [1]. Facial esthetics are a significant factor with regard to societal and selfperceptions [2]. One of the the most important components of orthodontic diagnosis and treatment planning is evaluating the patient's soft tissue profile $[3,4]$. Subtelny, Burstone, Bowker, and Meredith recommended using a soft tissue analysis to correctly evaluate any underlying skeletal discrepancies because of individual differences in soft tissue thickness [3,5].

A comprehensive soft-tissue analysis of the face is vital, as the soft-tissue profile may differ between different age groups, sexes, and ethnic groups [6]. The Chinese ethnic group categorized as the Mongoloid race tends to have a flat facial profile and a more prominent zygomatic arch [7]. Several methods have been developed to analyse facial profiles, such as anthropometry, photometry, and cephalometry 
$[3,6,8]$. Leung et al. conducted a 2014 study in Hong Kong using a random sample of 514 subjects ( 259 males and 255 females). Profile pictures were taken in the natural head position and the angle was calculated using the G-Sn-Pog landmark. The results showed that males tended to have a more convex profile than that of females [9] . Another study conducted by Othman et al. in 2016 was comprised of 109 Malays (54 males and 55 females). Convexity calculated using the G-Sn-Pg showed that the Malay ethnic group had a convex facial profile [10].

Studies that have conducted facial profile analyses had been performed on the Proto-Malay, Deutro-Malay, and India Tamil ethnic groups but seldomly are they found on Chinese ethnic groups; therefore, we conducted a facial profile analysis of Chinese high school students at W.R. Supratman $1 \& 2$ in Medan.

\section{Materials and Method}

This was a descriptive study with a cross-sectional design. The subjects were two grades of Chinese high school students (age, 15-18 years), who had never been treated with orthodontics, did not wear dentures, had complete permanent teeth eruption except M3, mild crowding $\leq 2 \mathrm{~mm}$, and competent lips. The 100 students were chosen using the stratified random sampling method.

Data were collected in two steps. Photographs were taken of all subjects, and the photos were edited by adding landmark points and lines after calculating the angles using software. We conducted a questionnaire study and checked the intraoral and extraoral environments of the students according to the inclusion and exclusion criteria. Photos were taken with the subject sitting in a chair $0.75 \mathrm{~m}$ in front of a wall covered with a $1.2 \times 1.5 \mathrm{~m}$ white cloth and a tripod to hold the Canon $\mathrm{g} 7 \mathrm{x}$ camera, which was placed $1.5 \mathrm{~m}$ in front of the subject's chair. The subjects were asked to remove their glasses or anything else that could block the face. They sat facing left to show the right part of the face to the camera at a point as high as the eyes (natural head position).

After the photos were taken, the landmark points and line was added according to the Graber and Singh method guide using Corel Draw X5 software. The angles were measured using ImageJ software. The landmark points on the lateral photograph using the Graber method were the glabella, upper lip contour, lower lip contour, and pogonion (Fig 1). The landmark line on the lateral photograph was a line that connected the forehead and the A point on soft tissue and a line connecting the A point on the soft tissue to the pogonion when using the Singh method and Corel Draw X5 software (Fig 2). The angles in each photo were measured using ImageJ software and then categorized into straight, convex, or concave (Fig 3 ).

Males with a facial profile angle of $145.12-161.86^{\circ}$ and females with a facial profile angle of $149.10-165.29^{\circ}$ were classified as the straight profile based on the glabella-upper lip contour-lower lip contour-pogonion angle. Males with a facial profile angle $>161.86^{\circ}$ and females with a facial profile angle $>165.29^{\circ}$ were classified as convex. Males with a facial profile angle $<145.12^{\circ}$ and females with a facial profile angle $<149.10^{\circ}$ were classied as concave. 


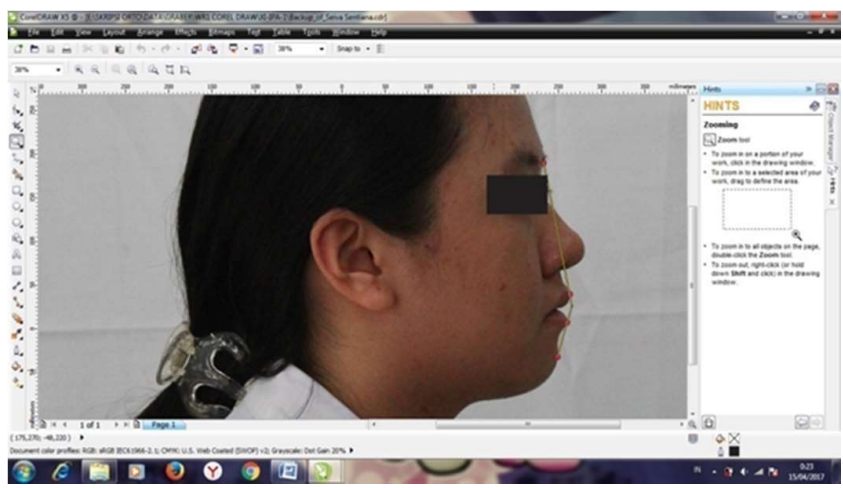

Fig 1. Graber landmarks added using Corel Draw X5 software

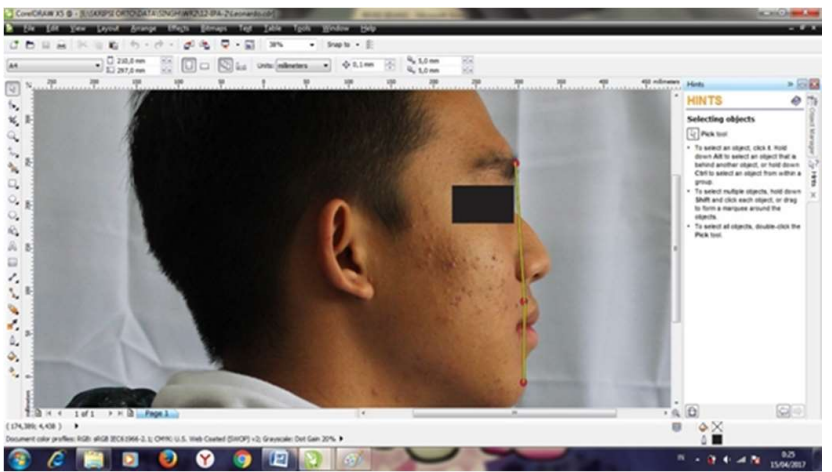

Fig 2. Singh landmarks added using Corel Draw X5 software

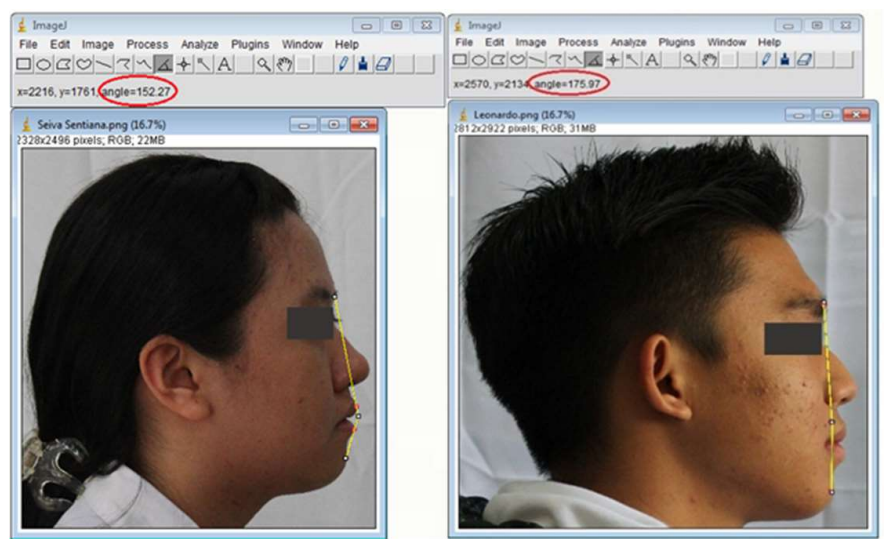

Fig 3. The angles in each profile photo were measured using ImageJ software 


\section{Results}

A total of 100 Chinese high school students at W.R. Supratman $1 \& 2$ were included in this study ( 50 males and 50 females). Average facial profile angle value of the Chinese high school students measured by the Graber method. The average male student's facial profile angle was $153.49^{\circ}$ with a standard deviation of $8.37^{\circ}$ whereas the average female student's facial profile angle was $157.19^{\circ}$ with a standard deviation of $8.1^{\circ}$. The average facial profile angle of the Chinese high school students measured using the Singh method. Male student's facial profile average angle was $171.05^{\circ}$ with a standard deviation of $5.52^{\circ}$, whereas that of females was $171.6^{\circ}$ with a standard deviation of $5.56^{\circ}$. Facial profile distribution based on gender using the Graber method. Most of the students had the straight profile, which comprised $62 \%$ of males and $68 \%$ of females followed by the convex profile which comprised $20 \%$ of males and $16 \%$ of females. The concave profile had the lowest percentage, which was $18 \%$ of males and $16 \%$ of females $(p>0.05)$. The facial profile distribution based on gender using the Singh method. Most of the students had the straight profile, which was comprised of $70 \%$ of the males and $62 \%$ of the females followed by the concave profile comprised of $8 \%$ of males and $22 \%$ of females. The convex profile had the lowest percentage among which was $14 \%$ of males and $22 \%$ of females ( $p>0.05$ ). The differences between the Graber and Singh methods for the facial profile analysis by photometry as examined by Fisher's exact test $(\mathrm{p}=0.004)$.

\section{Discussion}

Facial appearance is influenced by age, sex, race, and ethnicity [2,11]. Most clinicians have concluded that there are significant differences between diverse ethnic and racial groups, indicating that normal measurements for one group should not be considered normal for every other race or ethnic group. Different racial groups must be treated according to their own characteristics [12].

The average facial profile angle values of Chinese high school students measured by the Graber method. The average facial profile angle of the male students was $153.49^{\circ}$ with a standard deviation of $8.37^{\circ}$ whereas that of the female students was $157.19^{\circ}$ with a standard deviation of $8.1^{\circ}$. This study was different compared to that of Susilowaty at Hasanuddin University using 50 subjects of Bugis ethnicity as samples. That study was based on the Subtelny method to measure soft tissue convexity. Their results showed that average facial profile angle for males was $159.05^{\circ}$ with a standard deviation of $4.21^{\circ}$ and $162.77^{\circ}$ for females with a standard deviation of $4.42^{\circ}$ [4]. The significant difference was caused by the different methods used between studies.

The average facial profile angle values for Chinese high school students measured by on Singh method. The average facial profile angle of the male students was $171.05^{\circ}$ with a standard deviation of $5.52^{\circ}$, whereas that of female students was $171.6^{\circ}$ with a standard deviation of $5.56^{\circ}$ This study differed from that of Mush et al. who sampled 150 ( 78 males and 72 females) subjects at Swami Vivekanand Subharti University, Meerut, north India with a range of 18-25 years and class I angle occlusions. That study was based on Arnett's method. The results showed that the 
average soft tissue facial angle for males was $168.54^{\circ}$ with a standard deviation of $3.23^{\circ}$ and $166.64^{\circ}$ for females with a standard deviation of $4.09^{\circ}$ [7]. The difference was caused by the different races examined between the studies.

Adibah sampled 109 subjects of Malay ethnicity (54 males and 55 females) in her study conducted in Kuala Lumpur, Malaysia. This study was based on Arnett's method and the results showed that average facial profile angle for males was $166.91^{\circ}$ with a standard deviation of $5.21^{\circ}$ and $169.52^{\circ}$ with a standard deviation of $4.6^{\circ}$ for females [10]. Cindy et al. conducted a study in Hong Kong, China with 278 subjects (166 males and 112 females). The results showed that the average facial profile angle of males was $168.10^{\circ}$ with a standard deviation of $5.1^{\circ}$ and that of females was $168.85^{\circ}$ with a standard deviation of $4.83^{\circ}$ [9]. These results were similar to those of the present study because the samples were taken from the same race.

The facial profile distribution based on gender by the Graber and Singh methods. The present study differed compared to Jarungidanan et al. who conducted their study in the Orthodontic Department of Chulalongkorn University. That study was based on the Legan and Burstone method. The results showed that the convex facial profile was mostly found in males, and straight and concave had similar proportions. Straight, convex, and concave profiles comprised the same percentages in females [13]. The difference between these study results and those of the present study was caused by the different methods used. The differences between the Graber and Singh methods in the facial profile analysis on Chinese W.R.Supratman $1 \& 2$ high school students by photometry that was analyzed with Fisher's exact test $(\mathrm{p}=$ 0.004).

\section{Conclusions}

Several methods are available to analyze facial profiles, such as anthropometry, photometry, and cephalometry. This study used photometry. Anthropometry and photometry provide a simple way to obtain information, but are not as detailed as cephalometry, which is the gold standard in orthodontics. The following conclusions were drawn within the limitations of this study: (1) Chinese high school students at W.R. Supratman $1 \& 2$ in Medan tended to have a straighter facial profile according to the Graber and Singh methods; (2) The gender of the subjects had no significant effect on the facial profile.

\section{Acknowledgement}

The author thanks Hilda Fitria Lubis, DRG., Sp.Ort from the Department of Orthodontics, Faculty of Dentistry,University of North Sumatra, Medan.

\section{References}

1. Budianto E, Purwanegara MK, Siregar E. Karakteristik profil jaringan lunak pada penderita obstruksi saluran napas atas dengan kebiasaan bernapas melalui mulut. J Dent Indonesia. 2013 Jul 19;15(1):44-9.

2. Fortes HN, Guimarães TC, Belo IM, Matta EN. Photometric analysis of esthetically pleasant and unpleasant facial profile. Dent Press J Orthodons. 2014;19(2):66-75. 
3. Malkoç S, Demir A, Uysal T, Canbuldu N. Angular photogrammetric analysis of the soft tissue facial profile of Turkish adults. Eur J Orthodont. 2008;31(2):174-9.

4. Susilowati S. Hubungan antara derajat konveksitas profil jaringan keras dan jaringan lunak wajah pada suku Bugis dan Makassar. J Dentomaxillofac Sci. 2016;8(2):125-30.

5. Moshkelgosha V, Fathinejad S, Pakizeh Z, Shamsa M, Golkari A. Photographic facial soft tissue analysis by means of linear and angular measurements in an adolescent persian population. The Open Dent J. 2015; 9:346.

6. Ezeuko VC, Eboigbe PO. Angular photogrammetric analysis of the facial profile of the adults of Bini ethnicity of Nigeria. Annals Bioanthropol. 2015;3(1):14.

7. Kurnia C, Susiana S, Husin W. Facial indices in Chinese ethnic students aged 20-22. J Dent Indonesia. 2013;19(1):1-4.

8. Reddy M, Ahuja NK, Raghav P, Kundu V, Mishra V. A computer-assisted angular photogrammetric analysis of the soft tissue facial profile of North Indian adults. J Indian Orthodon Soc. 2011;45(3):119-23.

9. Leung CS, Yang Y, Wong RW, Hägg U, Lo J, McGrath C. Angular photogrammetric analysis of the soft tissue profile in 12-year-old southern Chinese. Head Face Med. 2014;10(1):56.

10. Othman SA, Majawit LP, Hassan WN, Wey MC, Razi RM. Anthropometric study of three-dimensional facial morphology in malay adults. PloS one. 2016;11(10): $\mathrm{e} 0164180$

11. Asghari A, Rajaeih S, Hassannia F, Tavakolifard N, Neisyani HF, Kamrava SK, Jalessi M, Omidian P. Photographic facial soft tissue analysis of healthy Iranian young adults: anthropometric and angular measurements. Med J Islamic Republic of Iran. 2014; 28:49.

12. Chhajed S, Kodumuru S, Singh G, Arun AV, Cholleti SK, Kothari S. Facial soft tissue cephalometric norms in a central Indian ethnic population. J Indian Ortho Soc. 2014;48(1):7-13.

13. Jarungidanan $P$,Sorathesn K. Acceptable facial profiles in Thai non-straight profile patients. CU Dent J 2008;31:235-48. 